\author{
Sebastian Latocha \\ Uniwersytet Łódzki \\ Wydziat Filozoficzno-Historyczny \\ Instytut Etnologii i Antropologii Kulturowej \\ sebastian.latocha@uni.lodz.pl
}

\title{
Etnografia w archiwum. Chłopskie podania o ziemię poniemiecką w gminie Lazisko w centralnej Polsce Antropologiczny przyczynek do Historii Alternatywnej reformy rolnej (1944)
}

\begin{abstract}
Zatrwożyła mnie jednak ta myśl, chociaż była błoga. Zerwałem się z progu, rozglądając się niepewnie dookoła. Nigdzie żywej duszy. Nawet psy, które nie tak dawno rzucaty się za ludźmi, skryty się gdzieś w zaciszach, pocichty. Nawet krowa nigdzie nie zaryczała, koń nie zarżał, paw nie zaskrzeczat. Poczułem się nagle w tej pustce tak, jakby nie było ludzi, ale i mnie samego nigdzie nie było. Chciało mi się za kimś wołać, ale nie wiedziałem za kim, nie bytem pewny, czy wołanie moje do kogokolwiek dojdzie. Chciało mi się uciekać, ale nie wiedziałem gdzie, a za ludźmi było już za późno ${ }^{1}$.
\end{abstract}

\section{Reforma rolna (1944) wobec wiejskich osadników niemieckich}

Artykuł ma na celu przede wszystkim przedstawienie części chłopskiego doświadczenia reformy rolnej (1944) ${ }^{2}$ oraz chłopskich podań o przydział ziemi po niemieckich osadnikach $\mathrm{w}$ gminie Łazisko $^{3}$. Wybór miejsca jest celowy - to od

1 W. Myśliwski, Pałac, Wydawnictwo Znak, Kraków 2010, s. 11.

2 W niniejszym artykule pojęcia - „reforma rolna (1944)” oraz „reforma rolna” - odnoszą się do szeregu okoliczności historycznych, jakie miały miejsce w związku z realizacją idei Dekretu Polskiego Komitetu Wyzwolenia Narodowego z dnia 6 września 1944 r. o przeprowadzeniu reformy rolnej, Dz.U. 1944 nr 4 poz. 17.

3 Gmina Łazisko z siedzibą w Ujeździe to historyczna jednostka administracyjna; współcześnie jej obszar pokrywa się z południowo-wschodnią częścią gminy Ujazd i północno-wschodnią częścią gminy Tomaszów Mazowiecki (pow. tomaszowski, woj. łódzkie). Obecny podział administracyjny Polski nie uwzględnia gminy Łazisko. Zlokalizować ją pozwala, trwalsza od podziałów administracyjnych, sieć rzeczna. Dawna gmina Łazisko leżała w widłach niewielkich rzek zasilających wody Pilicy: Bieliny (lokalna nazwa środkowego biegu rzeki Czarnej) i znajdującej w niej swoje ujście Piasecznicy. 
połowy XVIII w. prawie do końca lat 40 . XX w. wielokulturowa gmina z wyraźnym rysem niemieckiego osadnictwa wiejskiego ${ }^{4}$.

Liczne egzegezy i wiwisekcje - naukowe i artystyczne ${ }^{5}$ - reformy rolnej skupiają się głównie na politycznych, ekonomicznych, społecznych, kulturowych, etycznych i psychologicznych aspektach „,przesunięcia” własności między warstwami ziemiańską i chłopską w myśl art. 2 ust. 1 lit. e „Dekretu”. Na przykład, przedmiotem refleksji Anny Wylegały jest chłopskie doświadczenie reformy rolnej, ale tylko w kontekście relacji z warstwą ziemiańską ${ }^{7}$. Wylegała doceniła sferę ludzkich emocji towarzyszących reformie rolnej, lecz w społeczno-kulturowym krajobrazie wsi nie zwróciła uwagi na liczną w skali całego państwa polskiego grupę osadników niemieckich, o których losie przesądziła lit. b ust. 1 art. 2 „Dekretu”. Wydaje się, że w polskiej pamięci społecznej o reformie rolnej (1944) pierwszorzędność problemu wywłaszczenia warstwy ziemiańskiej na rzecz chłopów (jako sprawiedliwości dziejowej) dezawuuje podobne doświadczenie innej grupy. Być może korzenie takiego stanu rzeczy tkwią w etnocentryzmie, który bazuje na grupowej lojalności. Ekscentryzm zaś (który jest atrybutem mojego artkułu) tę lojalność łamie, oświetlając i problematyzując kwestię wywłaszczenia niemieckich osadników wiejskich ${ }^{8}$.

Choć przedwojennej agrarystycznej ${ }^{9}$ koncepcji reformy rolnej towarzyszył radykalizm, to nie godziła w interesy wiejskich osadników niemieckich tak, jak reforma rolna (1944). Andrzej Lech, rekonstruując myśl społeczno-polityczną Związku Młodzieży Wiejskiej RP „Wici”, konstatuje: „Chłop miał reprezentować najcenniejsze wartości społeczne i moralne. Jego gospodarstwo, obrabiane samodzielnie, przy udziale rodziny, powinno być efektywniejsze ekonomicznie od wielkiej własności ziemskiej i także dlatego stanowić powszechną formę własności w rolnictwie, jako podstawie gospodarki narodowej. Zbieżny jest więc z interesem całego polskiego społeczeństwa postulat reformy radykalnej, opartej o zasadę wywłaszczenia tych wszystkich, którzy nie pracują na roli osobiście

$4 \quad$ Niemieckie osadnictwo wiejskie w Polsce centralnej panoramicznie portretuje K.P. Woźniak, Niemieckie osadnictwo wiejskie między Prosna a Pilica i Wista od lat 70. XVIII wieku do 1866 roku. Proces i jego interpretacje, Wydawnictwo Uniwersytetu Łódzkiego, Łódź 2013.

5 Wśród nich powieść Myśliwskiego, której wyimek jest mottem artykułu, stanowi dobry przykład. Co czuli chłopi, jakie emocje nimi targały w obliczu radykalnej metamorfozy struktury i krajobrazu społeczno-kulturowego po II wojnie światowej?

6 W niniejszym artykule dotyczy: „Dekret Polskiego Komitetu Wyzwolenia Narodowego z dnia 6 września 1944 r. o przeprowadzeniu reformy rolnej”, Dz.U. 1944 nr 4 poz. 17.

7 A. Wylegała, O perspektywie badania chłopskiego doświadczenia reformy rolnej. Z warsztatu badawczego, ,Rocznik Antropologii Historii”, 2017, R. VII (10), s. 273-305.

8 Postawa ekscentryczna nie jest efektem braku wiedzy o tragicznych dla polskich chłopów okolicznościach II wojny światowej oraz całym kontekście historycznym i propagandowym, lecz jest świadomym wyborem perspektywy badawczej dotąd niepopularnej.

9 Homologiczna z ideą agraryzmu jako ruchu społeczno-politycznego (m.in. Związku Młodzieży Wiejskiej RP „Wici”), dla którego rolnictwo było/jest podstawą gospodarki narodowej. 
i jednocześnie uwłaszczenia tych, którzy ziemi maja za mało, by spełnić swą misje społeczną i ekonomiczną" ${ }^{10}$. Wiejscy osadnicy niemieccy w gminie Łazisko, choć na tle polskich chłopów wyróżniali się pod względem proweniencji, języka i wyznania, to pracowali na roli osobiście, z chłopami etnicznie polskimi wspólnie kreując lokalne krajobrazy, a i tak spotkało ich wywłaszczenie w myśl lit. b ust. 1, art. 2 „Dekretu” oraz repatriacja.

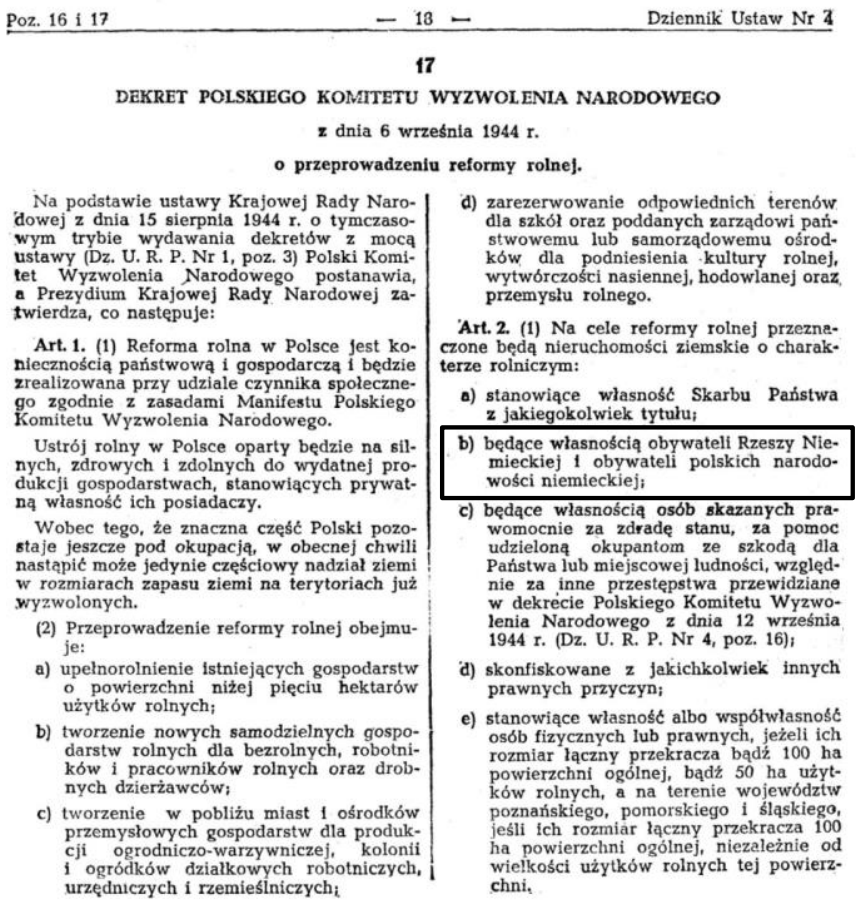

Ryc. 1. Inicjalna część Dekretu Polskiego Komitetu Wyzwolenia Narodowego z dnia 6 września 1944 r. o przeprowadzeniu reformy rolnej, Dz.U. 1944 nr 4 poz. 17.

W ramce znajduje się kluczowy (z perspektywy przedmiotu artykułu) fragment Dekretu. Źródło: http://prawo.sejm.gov.pl/isap.nsf/DocDetails.xsp?id=WDU19440040017

$\overline{10}$ A. Lech, ,Nowy wspólny dom”. Myśl społeczno-polityczna Związku Młodzieży Wiejskiej RP ,Wici”, Muzeum Historii Polskiego Ruchu Ludowego, Warszawa 2018, s. 87. 


\section{Dokumenty w etnografii / antropologii kulturowej}

Artykuł prezentuje tylko wyimek bogatego materiału ${ }^{11}$ źródłowego - chłopskie podania o poniemiecką ziemię - lokującego się na granicy dokumentów oficjalnych i nieoficjalnych oraz stanowiącego ciekawy przedmiot do badań etnograficznych. Podania, choć ich domeną jest obieg formalny i publiczny, mają charakter nieformalny i prywatny - manifestują autentyczne ludzkie przeżycia, emocje, ambicje, marzenia, kłopoty, lęki czy opresje.

Zgłębiając kwestię chłopskiego doświadczenia reformy rolnej w wielokulturowej gminie Łazisko, liczyć mogę na dwa rodzaje źródeł: pamięć i dokumenty. Ta pierwsza - minęło wszak 70 lat od reformy - jest pamięcią przede wszystkim tych, którzy w latach 40. XX wieku byli dziećmi; te drugie zaś są na wyciągnięcie ręki. Częśsią spuścizny po reformie są właśnie dokumenty. Michał Łuczewski i Paulina Bednarz-Łuczewska konstatują: „Kiedy mija pamięć, opowiedzieć o przeszłości mogą już tylko dokumenty. Nic dziwnego zatem, że historycy, ci spóźnieni socjologowie, opierają swoją dyscyplinę na pracy w archiwum. W ostatecznym rozrachunku dokumenty okazują się jednak źródłem poznania nie tylko naszej historii, lecz także teraźniejszości" ${ }^{12}$. Będące przedmiotem mojej refleksji dokumenty jako źródło poznania „naszej historii” wzbogacają wiedzę o powojennym losie niemieckich mieszkańców Polski centralnej i stosunku do niego chłopów - beneficjentów reformy. Jako źródło poznania teraźniejszości otwierają zaś perspektywę deszyfracji współczesnego krajobrazu kulturowego poniemieckich wsi i dynamiki form pamięci ich współczesnych mieszkańców.

Stereotypowo różnicę między historią i etnografią/antropologią kulturową opiera się na różnicy podstawowych źródeł. Historia kojarzona jest $\mathrm{z}$ dokumentami i archiwami, a wywiady i obserwacje są domeną etnografii/antropologii. Jednak w praktyce dyscypliny te nie egzystują jako alternatywy, przeciwnie - współcześnie wzajemnej inspiracji sprzyja klimat interdyscyplinarności. Koligacje tych dyscyplin są przedmiotem refleksji w humanistyce ${ }^{13}$ i mają swoje konkretne ma-

11 Archiwum Państwowe w Piotrkowie Trybunalskim - Oddział w Tomaszowie Mazowieckim, „Akta Gminy Łazisko z siedzibą w Ujeździe”, zespół nr 21: Rolnictwo i reforma rolna, 1945, sygn. 287; Urząd Reformy Rolnej. Podania na gosp. niem. odmówione. Ujazd, Maksymów, Stasiolas, Cekanów, Małecz, Olszowa-Piaski, Wólka Krzykowska, 1945, sygn. 288; Ewidencja Niemców z terenu gminy Lazisko, 1946-1947, sygn. 320; Ewidencja Niemców, 1948, sygn. 361; Niemcy (ewidencja ludności niemieckiej), 1949-1951, sygn. 390; Księga ludności stałej wsi: Bielina, Kol. Dębniak, Wygoda, Wólka, Folwark Teklów, Olszowa-Piaski, Maksymów, t. V, 1895-1931, sygn. 524.

12 M. Łuczewski, P. Bednarz-Łuczewska, Analiza dokumentów zastanych, [w:] Badania jakościowe. Metody i narzędzia, t. II, pod red. D. Jemielniaka, Wydawnictwo Naukowe PWN, Warszawa 2012, s. 163.

13 J. Barański, G. Godlewski, J. Jeszke i inni, Antropologia historii/antropologia historyczna w Polsce. Pojęcia - dziedzictwo - perspektywy. Ankieta, „Rocznik Antropologii Historii”, 2011, nr 1-2, s. 33-69; C. Geertz, Zastane światto. Antropologiczne refleksje na tematy filozoficzne, thum. Z. Pucek, Towarzystwo Autorów i Wydawców Prac Naukowych 
nifestacje. W ostatniej dekadzie polska humanistyka niejako „,powróciła do archiwum", o czym świadczą choćby tematyczne numery takich czasopism naukowych jak „Kultura Współczesna”14 czy „Kultura i Społeczeństwo”15. Choć polska etnografia/antropologia kulturowa ma swoje bogate archiwa (np. Etnograficzne Archiwum im. Bronisławy Kopczyńskiej-Jaworskej ${ }^{16}$, Cyfrowe Archiwum im. Józefa Burszty ${ }^{17}$ czy Archiwum Historii Mówionej Śląska Cieszyńskiego ${ }^{18}$ ), to do niedawna dyscyplina ta rzadko sięgała po dokumenty, $\mathrm{z}$ archiwami obchodząc się jak z produktami ubocznymi życia zbiurokratyzowanych, złożonych społeczeństw lub miejscami, w których żywot kończą materiały z badań terenowych. Archiwa były i są przedmiotami badań ${ }^{19}$. Dzisiaj - całe szczęście - przeżywają renesans i są źródłem etnograficznej wiedzy. „Nie ma bowiem żadnego powodu, żeby badacz społeczny rezygnował z cennego, a często jedynego źródła informacji” ${ }^{20}$.

\section{Alternatywne podejście}

Ewa Domańska o tzw. Historii Alternatywnej: „proponuje zupełnie inny punkt patrzenia na historię i inną jej panoramę. Opowiada ona o człowieku, który został »wrzucony« w świat, o ludzkim byciu w świecie, o ludzkim doświadczaniu świata i o sposobach tego doświadczania. Człowieka i jego losy poznajemy za pośrednictwem cases (przypadków), mikrohistorii, antropologicznych opowieści, które jak sonda pozwalają wniknąć w codzienną rzeczywistość"21. Historia

UNIVERSITAS, Kraków 2003, s. 151-170; A. Guriewicz, Historia i antropologia historyczna, „Konteksty. Polska Sztuka Ludowa” 1997, nr 1-2, s. 13-21; E. Domańska, Mikrohistorie. Spotkania w międzyświatach, Wydawnictwo Poznańskie, Poznań 1999, s. 63-75; K. Pomian, Historia - dziś, [w:] Historia -dziś. Teoretyczne problemy wiedzy o przeszłości, pod red. E. Domańskiej, R. Stobieckiego, T. Wiślicza, Towarzystwo Autorów i Wydawców Prac Naukowych UNIVERSITAS, Kraków 2014, s. 19-36; J. Tokarska-Bakir, Okrzyki pogromowe. Szkice z antropologii historycznej Polski lat 1939-1946, Wydawnictwo Czarne, Wołowiec 2012, s. 231-232.

14 Powrót do archiwum, „Kultura Współczesna” 2011, nr 4.

15 Społeczne w archiwach, „Kultura i Społeczeństwo” 2019, nr 1.

16 G.E. Karpińska, Co znajdziemy w Etnograficznym Archiwum im. Bronisławy Kopczyńskiej-Jaworskiej, „Kultura i Społeczeństwo” 2019, nr 1, s. 125-131.

17 A. Stanisz, Cyfrowe Archiwum im. Józefa Burszty, czyli otwarta etnografia, „Kultura i Społeczeństwo" 2019, nr 1, s. 133-141.

18 G. Kubica, A. Doboszewska, Archiwum Historii Mówionej Ślaska Cieszyńskiego - spoteczny projekt otwarty, „Kultura i Społeczeństwo” 2019, nr 1, s. 143-151.

19 M. Łuczewski, P. Bednarz-Łuczewska, dz. cyt., s. 163-164; M. Krajewski, Od redakcji, „Kultura i Społeczeństwo” 2019, nr 1, s. 3-5

20 M. Łuczewski, P. Bednarz-Łuczewska, dz. cyt., s. 164.

21 E. Domańska, Historiografia czasu postmodernizmu po postmodernizmie (retrospekcja), „,Łódzkie Studia Etnograficzne”, t. 35, s. 113. 
Alternatywna - cytując Dariusza Czaję - „dorzuca nowy głos do głosów już istniejących, ale nie zgłasza pretensji do jedyności i apodyktycznej pewności”22. Jej alternatywność nie opiera się na chęci substytucji historii tradycyjnej (w tej mierze jest w stosunku do niej właściwie komplementarna), ale na nieschematycznym, antropologicznym podejściu. „Historycy próbują spojrzeć na stare kwestie (na przykład władza polityczna) czy znane dokumenty (na przykład zapiski inkwizycji) w odmienny sposób. Zachowania i przekonania, tradycyjnie uznawane za bezsensowne, nieważne i marginalne kurioza (np. magia czy przesądy) zaczęto analizować w kategoriach ważnych ludzkich przeżyć (historical experiences)"23.

Ważną częścią paradygmatu Historii Alternatywnej jest przejście: „od zachowań do przeżyć, od bez mała behawiorystycznych opisów do prób odsłaniania subiektywności badanych postaci: ich motywacji, dążeń, lęków, nadziei, rozterek, złudzeń i innych stanów psychicznych"24. To właśnie one w chłopskich podaniach o ziemię poniemiecką $\mathrm{w}$ gminie Łazisko interesują mnie, jako antropologa, najbardziej.

Alternatywność tego podejścia przejawia się w: „wyprowadzaniu historii z granic państw czy narodów oraz skupieniu uwagi na ogólnoludzkiej wspólnocie cierpienia niż na sukcesach jednej grupy, choćby własnej, odniesionych kosztem pozostałych" ${ }^{25}$. Optyka partykularna, niestety, dezawuuje problemy dotyczące kondycji ludzkiej, co Adam Zagajewski określa „ciasnym, beznadziejnym zaułkiem”. Jakie jest z niego wyjście? „Zapewne wiąże się ze zdolnością do odwrócenia spojrzenia od nas samych, $z$ odwagą stłuczenia tego lustra, w którym wciąż się pokazuje nasze smętne oblicze, i ze skierowaniem uwagi na fundamentalne pytania, dotyczące tego, czym jest byt, czym jest człowiek, czym jest świat w swej całości" 26 .

Istotą antropologicznej lektury podań chłopów o ziemię niemieckich osadników jest „zanurzenie się” pod powierzchnię faktów historycznych i okoliczności propagandowych, do głębin uniwersalnej, kulturowej dychotomii swój-obcy. „Skoro zło jest banalne - suponuje w innym kontekście Slavenka Drakulić - to znaczy, że w pewnych okolicznościach każdy z nas może stać się zbrodniarzem. Nikt nie jest bezpieczny. Nikt nie może przesądzić z góry, jak się zachowa w określonej sytuacji”"

22 D. Czaja, Znaki szczególne. Antropologia jako ćwiczenie duchowe, Wydawnictwo Uniwersytetu Jagiellońskiego, Kraków 2013, s. 8.

23 C. Ginzburg, Anthropology and History in the 1980s. A Comment, [w:] The New History. The 1980s and Beyond. Studies in Interdisciplinary, pod red. T.K. Rabb, R.I. Rotberg, New Jersey 1982, s. 277-278. Cyt. za: E. Domańska, Historiografia ..., s. 113-114.

K. Pomian, $d z$. cyt., s. 22.

25 Tamże, s. 24.

26 A. Zagajewski, Substancja nieuporzadkowana, Wydawnictwo Znak, Kraków 2019, s. 26-27.

27 S, Drakulić, Ciało z jej ciała. O banalności dobra, thum. D. Kozińska, Wydawnictwo W.A.B., Warszawa 2012, s. 26. 
Lekturę prezentowanego $\mathrm{w}$ artykule materiału archiwalnego sytuuję $\mathrm{w}$ atmosferze myśli Arona Guriewicza: „każdy historyk spotyka się w swoich badaniach ze społeczno-psychologiczną stroną historii, gdyż trudno znaleźć takie historyczne źródło, które nie nosiłoby na sobie śladów mentalności ludzi, którzy je stworzyli" ${ }^{28}$. Dlatego lekturę chłopskich podań o poniemiecką ziemię w gminie Łazisko w centralnej Polsce proponuję oprzeć na kategoriach rodem z psychologii społecznej (np. schemat, atrybucja, konformizm).

Alternatywność mojego podejścia w egzegezie reformy rolnej (1944) składa się, przede wszystkim, z:

- przesunięcia perspektywy z makrohistorycznej na mikrohistoryczną,

- skupienia się na dokumentach (podaniach) lokujących się na pograniczu oficjalności i nieoficjalności (obiektywności i subiektywności, faktów i sfery emocji),

- wyprowadzenia historii z granic narodowych (na rzecz skoncentrowania się na ogólnoludzkim cierpieniu),

- charakterystycznego dla przeciw-historii ${ }^{29}$ bycia dyskursem „odszyfrowania, odgrzebania sekretu, odwrócenia podstępu, odzyskania przeinaczonej lub stłumionej wiedzy. Będzie to odczytywanie prawdy zapieczętowanej”30.

\section{Podania o ziemię poniemiecką w gminie Lazisko}

$\mathrm{Z}$ całego materiału źródłowego wybrałem 10 przykładowych podań ${ }^{31}$, kierując się przede wszystkim imperatywem przedstawienia różnych argumentacji, emocji i biograficznych przeżyć chłopów aplikujących o ziemię poniemiecką w gminie Łazisko.

\section{Podanie 1.}

[Bolesław Pakowski, Stasiolas, 06.02.1945 r.]

Prosze o przydzielenie mi ziemi poniemieckiej

po Sztajnbarcie i Szeflerze w Kolonij Ujazd

razem 9 ha.

Życiorys

Bolestaw Pakowski syn Franciszka $i$

Maryanny ur. w. 1900. w Olszowie gm. Łazisko

Do szkoły powszechnej uczęszczatem w Olszowie

28 A. Guriewicz, dz. cyt. s. 13.

29 Zob. M. Foucault, Trzeba bronić spoteczeństwa. Wykłady w Collège de France, 1976, thum. M. Kowalska, Wydawnictwo KR, Warszawa 1998, s. 71--89.

30 Tamże, s. 78.

31 Cytowane podania pochodzą z Archiwum Państwowego w Piotrkowie Trybunalskim, Oddziału w Tomaszowie Mazowieckim, „Akta Gminy Łazisko z siedzibą w Ujeździe”, zespół nr 21, sygn. 288. Pisownia oryginalna. 
ukończytem 2 oddziały. Od najmtodszych lat

pracowatem $w$ gospodarstwie przy ojcu.

1926 r. nabylem gospodarstwo w Kolonij Ujazd

$z$ parcelacji hrabiego Ostrowskiego, w najgorszej

kulturze a dziś jednakowosz doprowadzitem

do najlepszej kultury pomimo ciężkich warunków

wojennych i przed wojennych.

\section{Podanie 2.}

[Jan Woźniak, Olszowa, 16.02.1945 r.]

Posiadam gospodarstwo karlowate o powierzchnii

0,84 ha, ktore mi nie wystarcza na utrzymanie.

Przed wojna zarabiatem dodatkowo, aby módz wyżyć, wynajmując się do pracy najemnej u gospodarzy.

Podczas wojny, aby się uchronić przed wywiezieniem na roboty do Niemiec, zmuszony bytem pracować u Niemców za stużącego. Przez okres 2-letni od poczatku wojny byłem zatrudniony u Pufalda Ferdynandta $w$ Stasiolesie, później 2 i pót roku u Szefler Jadwigi w Kol. Ujazd, a ostatnio od od początku roku bieżacego zmuszony bytem u tego samego Pufalda Ferdynandta i do tej pory zamieszkuje tamże.

Wobec tego uprzejmie prosze o przyznanie mi wymienionego wyżej gospodarstwa poniemieckiego.

\section{Podanie 3.}

\section{[Jan Błażejewski, Stasiolas, 17.02.1945 r.]}

Ukończyłem szkołe powszechna trzy oddziały. Po ukończeniu szkoty pomagatem ojcu w gospodarstwie do 1944 rok.

W nastempnym roku zmuszony byłem przez niemców iść na stużbe do Udycha Jóliusza który miat w posiadaniu ziemie po Nyklu.

Uprzejmie prosze o przyznanie mi gospodarstwa p Niemcach Nyklu i Sznajdrze Gustafie poniewaz jesto jedno przy drugiem.

\section{Podanie 4.}

[Stefan Piasny, Dębniak, 23.02.1945 r.]

Niniejszym mam zaszczyt prosić o przydzieleni mi 
gospodarstwa po niemcach, to jest po Michale Jońskim lub (Rainolcie Sefler) zamieszkały w dębniaku.

Do podania swego zgłaszam krótki swój życiorys:

Jako syn Jana i Józefy Piasny zam. w Dębniaku

gm. Lazisko, urodz dnia 14.12.1920 r.

Od mtodych swych lat pracowatem $w$ gospodarstwie rolnem.

W czasie rozpoczecia wojny Polsko-niemieckiej zostałem

zabrany na podwode do wojska polskiego, z którem przebywatem

4 tygodnie.

W krótkim czasie po zajeciu polski przez Niemców, dnia 24.6

1940 r. zostatem przymusowo zabrany do niemiec, gdzie

pracowatem 3 lata w gospodarstwie przy lichych warunkach

do zycia, nie mogąc wytrzymać zrezygnowatem uciekając

z pod München $1040 \mathrm{~km}$ do granicy polskiej o głodzie

w porze zimowej do swego domu. Ро przybyciu dnia

17.12.1943 r. musiałem się ukrywać, jako posukiwany,

aby się nie dostać do wiezienia w ręce tyrani

hitlerowskiej.

Nie dlugi czas swego pobytu $w$ domu, zabrany przymusowo $z$

zawady po obstuga S.S. i S.A. i wywiezieni zostaliśmy na granice Łotewsko-Litewska, do ciężkiej pracy akortowej przy kopaniu, dołów strzeleckich, $i$ dużych dotów przeciw colgowych przy lichem wyzywieniu w ciezkiej pracy [dokument nieczytelny] pracowatem miedzy czasie od 30.8.1944 r. do 20.10.1944 r. Stamtąd musieliśmy uciekać po kará śmierci [dokument nieczytelny] się przed frontem, do prus wschodnich, gdzie ponownie zostaliśmy sformowani i odestani do okopów od królewca $80 \mathrm{~km}$ o lichem wyzywieniu jak wiadomo catemu Społeczeństwu Polskiemu pracowałem 2 tygodnie nie [dokument nieczytelny] wytrzymać przy ciezkiej pracy, zrezygnowatem, uciekajac $w$ strone granicy Polskiej, zostatem arestowany przez zadarmerjie niemiecka i na pieszo pod batami [dokument nieczytelny] $20 \mathrm{~km}$ do miasteczka gardau. Na jednym placu zostatem wystawiony pod mur, poczytywany jako partyzant na rozestrzat i juz tylko kilka minut było mozna [dokument nieczytelny] kiedy ostatni przyjdzie czas zycia mojego. Na ta chwile zajechat samochodem oficer zadarmeri i jeden porucznik zainteresowali się mojem błaganiem, po wystuchaniu [dokument nieczytelny] na widok thumu, jaki przypatrywat się mym ostatnim godzina zycia, rokazali, aby mnie odwiez do kólewca do ciezkiego wiezienia, gdzie zwieschictwo miato [dokument nieczytelny] tam siedziałem 4 dni o glodzie bity $i$ katowany. Czwartego dnia byto ostatnie [dokument nieczytelny] i zkazali mnie na 8 dni ciekiego wiezienia, gdzie o wodzie i 100 g. chleba na dzień. Usmego dnia zostatem zwolniony $z$ wiezienia $i$ [dokument nieczytelny] 
do posrednictwa pracy i przydzielony do piekarni wojskowej gdzie pilnowało niemieckie gestapo.

Pracujac tam 15 godzin o lichem wyzywieniu i lichem

wyspaniu pracowatem 4 tygodnie. Nie mogac wytrzymać

zrezygnowatem poraz 3 z tej pracy i z królewca pod wagonem

przyjechałem do mulawy, a z Muławy na pieszo do [dokument nieczytelny]

w porze zimowej do swego domu 24.12.1944 $r$.

Pod strachem, narazając się w każdej chwili na swoje życie

lub ciezki obóz.

Wiec uprzejmnie proszę wziac pod uwage moje

motywy i prosze o przydzieleni mi gospodarstwa po

niemcach.

Przez grzeczność prosi: Stefan Piasny zamieszkaty

w Dębniaku syn dużej rodziny liczacej 8 ludzi

a 12 morg ziemi piaszczystej, ze takiej rodzinie trudno wyzyć.

\section{Podanie 5.}

[Władysław Dębiec, Komorów, 25.02.1945 r.]

Podanie [...] o przyznanie praw dobrodziejstwa gospodarstwa po niemcu Teofilu

Kryze w Komorowe, gm. Łazisko.

Dobrodziejstwa praw gospodarstwa

przystuguja mnie z następujacych przyczyn:

Ja podpisany osadzony i osadzony przez.

okupantów niemców $w$ więzieniu przesiedziatem

50 dni, zabrali okupanci zięcia

Longina Deredasa do Oświęcima $i$

pozostała córka wraz z dwojga dziećmi

jest na moim wyłacznie utrzymaniu

co posiadane 5morgowe gospodarstwo

prawne nie daje samodzielnego utrzymania

i opieki nad pozostała rodzina.

Przeto proszę uprzejmie Wtadzę Starostwa

Powiatowego w Brzezinach za pośrednictwem Zarzadu Gminnego

o przyznanie mi praw [dokument nieczytelny]

i korzystania z dobrodziejstw gospodarstwa

rolnego po niemcu Teofilu

Kryze o przestrzeni 7.5 morgów czyli

4 ha 20 arów przylegajacych do mego

gospodarstwa rolnego o przestrzeni

5 morgów w Komorowie, gminy

Łazisko. 


\section{Podanie 6.}

\section{[Józef Dębiec, Komorów, 27.02.1945 r.]}

Prosze uprzejmie o przydzielenie mi ziemi po

Bercie Fuchs obejmujacej 4 ha 20 ar., oraz polowe

pobudynków.

Ziemi własnej posiadam 1 ha 80 ar. Moja ziemia

sasiaduje z ziemia Berty Fuchs.

Prośbę swoja motywuję tym, że pracowatem

przymusowo w tym gospodarstwie przez caty

okres okupacji niemieckiej i nie otrzymywatem

żadnego wynagrodzenia.

\section{Podanie 7.}

[Michał Jasiński, Olszowa, 08.03.1945 r.]

Posiadam 1,66 ha ziemi w Olszowej na której nie mogę wyżywić żonę i czworo dzieci. Uprzejmie prosze o przydzielenie mi ziemi poniemieckiej na upetnorolnienie mego kartowatego gospodarstwa. Przygarnatbym dokupna ziemi spadkowej po niemcu Pufald Jakubie w Stasiolesie $w$ takiej ilości, abym mógt samodzielnie się utrzymać. Ziemia ta mi najwięcej odpowiada gdyż znajduje się w niedalekiej odlegtości od mojej. Do gospodarowania posiadam konia i inwentarz martwy gdyż bytem dzierżawca 2 ha ziemi przez cata wojnę.

\section{Podanie 8.}

\section{[Jan Wąs, Zaborów, 12.03.1945 r.]}

Posiadam 1 ha 96 arów ziemi rodzina moja sktada

sie 5 osob jestem rolnikiem zamilowanym tak ze mnie nie wystarczy na wyzywienie mojej rodziny tak ze postanowitem prosić komisje o przydzielenie mnie dziatki ziemi 3 ha 64 arów po koloniście niemieckim Arturze Frydrichu który poszedt do armii niemieckiej $i$ zostat zabity a ostatnio to gospodarstwo byto dzierzawione przez Rajncholda Hama który wraz ze swoim towarzystwem wyjechat i nie wrócit a gospodarstwo pozostawit bez opieki a ja jako sasiad tej działki gdyż moja działka była kupiona od ich rodziny bo powyższa 
działka stanowita jedna catosc a jako prawowity syn tej ziemi chciałbym pozostać jej właścicielem które by stanowiło jedna całość jak przedtem.

\section{Podanie 9.}

[Stanisław Błażejewski, Stasiolas, 15.03.1945 r.]

Uprzejmie prosze o przydzielenie mi doти ро niemcu Zaksie Adolfie w Maksymowie gminy Łazisko ponieważ posiadam 3 h. 70 ar. ziemi własnej rodzina moja składa się z 6 osób, a nie posiadam zadnego budynku a zwłaszcza domu i niemam gdzie mieszkać.

Dotego czasu mieszkam w piwnicy od przechowywania kartofli ale dalej to jest nie możliwe tam mieszka po pierwsze ze jest bardzo ciasno i w dodatku wchodzi mi woda. A owtasnych siłach nie jestem $w$ stanie po budować, kamienie kture posiadatem na budowe zostaty mi zabrane przez władze niemieczkie $i$ wywiezione na budowe lotniska. Wobec tego prosze o przekazanie mi tego budynku.

\section{Podanie 10.}

[Stanisława Szewczyk, Kol. Ujazd, 18.03.1945 r.]

Proszę uprzejmie o przydzielenie mi gospodarstwa po niemieckiego po Janie Szeflerze w Maksymowie w obszarze 3 ha 36 ar. i zabudowanie gospodarskie tam jest a ja mieszkam teraz na komornem $i$ niemam żadnego wyjścia. Rodzina moja składa się z 4 osób najmłodsze dziecko ma 9 lat. Męża nie już trzy lata najstarszego syna 23 letniego rozerwata granata w Olszowie 23.II.1945 r. Życiorys

Stanisława Szewczyk córka 28 mogospodarza. Kacpra Wolaka i Stanisławy z Woźniaków. ur. w. 1897.19.IV. Łominy gm. Ciosny pow. Brzeziny. 
Do szkoły powszechnej uczęszczałam w Łominach.

Po ukończeniu 2 odd. pracowałam u ojca na

gospodarstwie rolnym. Gdy doszłam do petnoletności

wyszłam za Antoniego Szewczyka również

gospodarza i przeniostam się na wtasne

gospodarstwo az do wojny. Wojna zniszczyta

mnię do szczętu i musiatam pójść jako robotnica

do maj. Teklów, a mieszkać musiatam na komornym.

\section{Summary}

\section{Ethnography in the Archive. Peasant Applications for Former German Land in the Lazisko Commune in Central Poland. An Anthropological Contribution to the Alternative History of Land Reform (1944)}

The article - by probing / pipetting method - presents the Polish peasants' applications for former German land in the Lazisko commune from the period of land reform (1944). It opens a problem area and shows that the ethnographic / anthropological reading of documents, which are peasant applications for land, attempts to illuminate an old problems with a new light. The article is a contribution to the Alternative History of land reform, the axis of which is to examine the peasant experience of land reform in the context of relations with German settlers who disappeared from the common local cultural landscape. The alternativity or anthropology of the approach used is based on: shifting the perspective from a macro historic to a micro historic one, focusing on documents located on the border of formality and informality (objectivity and subjectivity, facts and sphere of emotions), deriving history from national borders (for the purpose of focusing on universal suffering), the discourse of counter-history.

Keywords: land reform, German settlers, Polish peasants, ethnography, Alternative History, rural studies

\section{Bibliografia}

Archiwalia i akty prawne

Archiwum Państwowe w Piotrkowie Trybunalskim - Oddział w Tomaszowie Mazowieckim, „Akta Gminy Łazisko z siedzibą w Ujeździe”, zespół nr 21:

Ewidencja Niemców, 1948, sygn. 361,

Ewidencja Niemców z terenu gminy Łazisko, 1946-1947, sygn. 320,

Księga ludności stałej wsi: Bielina, Kol. Dębniak, Wygoda, Wólka, Folwark Teklów, Olszowa-Piaski, Maksymów, tom V, 1895-1931, sygn. 524.

Niemcy (ewidencja ludności niemieckiej), 1949-1951, sygn. 390,

Rolnictwo i reforma rolna, 1945, sygn. 287, 
Urzad Reformy Rolnej. Podania na gosp. niem. odmówione. Ujazd, Maksymów, Stasiolas, Cekanów, Matecz, Olszowa-Piaski, Wólka Krzykowska, 1945, sygn. 288,

Dekret Polskiego Komitetu Wyzwolenia Narodowego z dnia 6 września 1944 r. o przeprowadzeniu reformy rolnej, Dz.U. 1944, nr 4, poz. 17.

\section{Opracowania}

Barański J., Godlewski G., Jeszke J. i inni, Antropologia historii/antropologia historyczna w Polsce. Pojęcia - dziedzictwo - perspektywy. Ankieta, „Rocznik Antropologii Historii”, 2011, nr 1-2, s. 33-69.

Czaja D., Znaki szczególne. Antropologia jako ćwiczenie duchowe, Wydawnictwo Uniwersytetu Jagiellońskiego, Kraków 2013.

Domańska E., Historiografia czasu postmodernizmu po postmodernizmie (retrospekcja), „Łódzkie Studia Etnograficzne”, 1996, t. 35, 111-129.

Domańska E., Mikrohistorie. Spotkania w międzyświatach, Wydawnictwo Poznańskie, Poznań 1999.

Drakulić S., Ciało z jej ciała. O banalności dobra, tłum. D. Kozińska, Wydawnictwo W.A.B., Warszawa 2012.

Foucault M., Trzeba bronić spoleczeństwa. Wyktady w Collège de France, 1976, thum. M. Kowalska, Wydawnictwo KR, Warszawa 1998.

Geertz C., Zastane światto. Antropologiczne refleksje na tematy filozoficzne, thum. Z. Pucek, Towarzystwo Autorów i Wydawców Prac Naukowych UNIVERSITAS, Kraków 2003.

Ginzburg C., Anthropology and History in the 1980s. A Comment, [w:] Rabb T.K., Rotberg R.I. (red.), The New History. The 1980s and Beyond. Studies in Interdisciplinary, New Jersey 1982.

Guriewicz A., Historia i antropologia historyczna, „Konteksty. Polska Sztuka Ludowa”, 1997, nr 1-2, s. 13-21.

Karpińska G.E., Co znajdziemy w Etnograficznym Archiwum im. Bronisławy Kopczyńskiej-Jaworskej, „Kultura i Społeczeństwo”, 2019, nr 1, s. 125-131.

Krajewski M., Od redakcji, „Kultura i Społeczeństwo, 2019, nr 1, s. 3-5.

Kubica G., Doboszewska A., Archiwum Historii Mówionej Śląska Cieszyńskiego - społeczny projekt otwarty, „Kultura i Społeczeństwo”, 2019, nr 1, s. 143-151.

„Kultura i Społeczeństwo”, 2019, nr 1 - Społeczne w archiwach.

„Kultura Współczesna”, 2011, nr 4 - Powrót do archiwum.

Lech A., „,Nowy wspólny dom”. Myśl społeczno-polityczna Związu Młodzieży Wiejskiej RP „,Wici”, Muzeum Historii Polskiego Ruchu Ludowego, Warszawa 2018.

Łuczewski M., Bednarz-Łuczewska P., Analiza dokumentów zastanych, [w:] Badania jakościowe. Metody i narzędzia, t. II, Jemielniak D. (red.), Wydawnictwo Naukowe PWN, Warszawa 2012, s. 163-188.

Myśliwski W., Pałac, Wydawnictwo Znak, Kraków 2010.

Pomian K., Historia - dziś, [w:] Domańska E., Stobiecki R., Wiślicz T. (red.), Historia - dziś. Teoretyczne problemy wiedzy o przeszłości, Towarzystwo Autorów i Wydawców Prac Naukowych UNIVERSITAS, Kraków 2014, s. 19-36.

Stanisz A., Cyfrowe Archiwum im. Józefa Burszty, czyli otwarta etnografia, „Kultura i Społeczeństwo", 2019, nr 1, s. 133-141.

Tokarska-Bakir, Okrzyki pogromowe. Szkice z antropologii historycznej Polski lat 1939-1946, Wydawnictwo Czarne, Wołowiec 2012.

Woźniak K.P., Niemieckie osadnictwo wiejskie między Prosna a Pilica i Wisła od lat 70. XVIII wieku do 1866 roku. Proces i jego interpretacje, Wydawnictwo Uniwersytetu Łódzkiego, Łódź 2013.

Wylegała A., O perspektywie badania chłopskiego doświadczenia reformy rolnej. Z warsztatu badawczego, „Rocznik Antropologii Historii”, 2017, R. VII (10), s. 273-305.

Zagajewski A., Substancja nieuporządkowana, Wydawnictwo Znak, Kraków 2019. 